
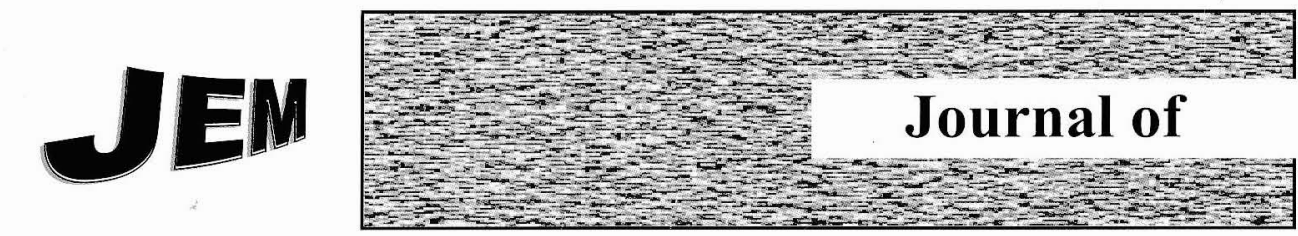

EDucational Management

A Bi-annual Publication of

THE INSTITUTE FOR EDUCATIONAL PLANNING AND ADMINISTRATION

(IEPA)

University of Cape Coast, Ghana

ISSN 0855 - $3343 \quad$ Vol. $6 \quad$ Nov. 2012 


\section{Investors In People: A Case Study of The Mathematics Department of Merton College, UK}

\section{Jonathan Fletcher}

\section{Abstract}

The Investors in People study of the Mathematics Department of Merton College was undertaken in November 2008 to determine the extent to which the Mathematics Department met the indicators of the new Standard introduced by Investors in People UK in 2005 in the face of the changes that were being implemented in the whole college. The study involved 14 out of the 23 staff in the department. The main instruments used were structured interview schedules, albeit relevant documents were also examined. The key finding was that generally, managers were able to demonstrate an understanding of how to count the costs and benefits of learning and development, and the latter's impact on the performance of individuals in the Mathematics Department. It was recommended that the Policy Team of the college should devetop an Action Plan to address some of the key issues identified in the study.

\section{Introduction}

The Investors in People Standard was developed in 1990 by the United Kingdom (UK) National Training Task Force, in partnership with leading business, personnel, professional and employee organisations. The Standard provides a national framework for improving business performance and competitiveness through a planned approach to setting and communicating business objectives and developing people to meet these objectives. It sets out a level of good practice for the training and development of people in order to achieve business goals. The Investors in People Standard has been a major UK success story in schools and other organisations since its introduction in 1990 (Investors in People UK, 2005). The Standard is based on three main principles:

Plan - develop strategies to improve performance.

Do - take action to improve the performance.

Review - evaluate the impact.

These three key principles are broken down into ten indicators, against which organisations wishing to be recognised as an Investor in People are assessed. The ten indicators are:

1. A strategy for improving the performance of the organisation is clearly defined and understood.

2. Learning and development is planned to achieve the organisation's objectives.

3. Strategies for managing people are designed to promote equality of opportunity in the development of the organisation's people. 
4. The capabilities managers need to lead, manage and develop people effectively are clearly defined and understood.

5. Managers are effective in leading, managing and developing people.

6. People's contribution to the organisation is recognised and valued.

7. People are encouraged to take ownership and responsibility by being involved in decision-making.

8. People learn and develop effectively.

9. Investment in people improves the performance of the organisation.

10. Improvements are continually made to the way people are managed and developed. (Investors in People UK, 2005, p 3).

The indicators are broken down further into 39 evidence criteria (See Appendix A). Investors in People UK was set up in 1993 to take ownership of the Standard and every three years, it reviews this to make sure that it is still relevant, accessible and beneficial to organisations of all types and sizes. Although the company is by definition UK based and orientated in its operations, interest from overseas has given the Standard an international dimension, both in terms of protection and development. In any organisation where the Standard is used for the purpose of assessment, the design of the review, the sampling method and the conduct of the review are all governed by Investors in People UK. Internal reviewers are advised to follow the guidelines provided by Investors in People UK. According to the company, the review report should use the following headings:

Overview of the organisation briefly describe the role and structure of the organisation including any special factors e.g. recent or proposed changes to the structure and procedures, staff moves, relocation or redundancies

Purpose and background to the review - explain the purpose of the review and how it fits in with the overall Internal Review strategy of the organisation.

Methodology - describe how you gathered evidence i.e. through one-toone interviews, focus groups and reference to supporting documents.

Overall conclusion - whether on the evidence from review, the Investors in People Standard is met or not met overall.

Areas of good practice - describe examples of good practice identified during the review.

Areas for development - describe significant areas for development identified during the review (Investors in People UK, 2005, p 9\& pp 21-22).

The study at Merton College followed the above guidelines although, as it will be shown later, the way data were collected reflected the needs of the College. The author, who is certified Internal Assessor, was commissioned by the Policy Team of the College to 
undertake the study in November, 2008.

\section{Overview of the Mathematics Department of Merton College}

Merton College, (referred to in this paper as "the College"), is an associate college of Kingston University. It is an attractive multicultural college currently situated on two green field sites at the outskirts of London. The College has two Centres of Vocational Excellence (CoVE) and enjoys a high reputation within a lively, challenging and competitive catchment area. The College was in the process of moving to a single site at the time of the study and this had resulted in some on-going structural changes.

The College offers a wide range of courses and programmes which provide progression to higher education, or to employment. The courses are also designed to update, retrain and enhance career prospects for those already in employment

The mission of the College is to:

1. make a significant contribution to economic success of employers and individuals and to the personal/social well-being of our students;

2. be learner centred in our approach, and to ensure success;

3. maintain a workforce that delivers excellence;

4. promote and celebrate our reputation for enabling and encouraging inclusion, diversity and equality; and

5. build capacity to provide excellent learning by diversi- fying its income sources and building its reputation as responsive and innovative institution. (Merton College Strategic Plan, 2008, p. 1).

Being an Investor in People (IIP), Merton College positively encourages equal access to education and aims to. provide quality service to all its students. This involves all of the workforce and is stated clearly in the College's plans for staff development (Merton College Strategic Plan, 2008.). Also, the College's equal opportunities policy states that all staff are considered to be equal and that the College seeks to support all of its employees through its management structures, training and development practices. This claim is part of what the Investors in People Standard was used to verify in the Mathematics Department of the College (referred to in this paper as "the Department"), which was undergoing a change as a result of the structural (and possibly cultural) changes that were being made in the College as a whole.

Structural changes are those changes that are concerned with the way functional units are organised to carry out their responsibilities. The focus includes policy and procedure, rules and regulations, management and staffing, facilities and equipment, and human resource practices (Kotter, 1996). Cultural changes, on the other hand, are concerned with the way people interact with each other, both in peer relationships and in superiorsubordinate relationships. Since cultural changes are to do with people, it is arguably the more difficult of the two to successfully deal with (Kotter, 
1996; Senior \& Flemming, 2005).

Indeed, the human systems of an enterprise are what make or break any change initiative. As McGregor (1960) observes in his 'Theory Y', such systems work well if they are based on trust and positive view of humanity. The College claims to be a people's college and prides itself on its Investors in People status. The main research question therefore was: what impact did the changes have on the Mathematics Department of the College?

The Department is part of the School of Academic Studies and is in the same programme area as the Science Department and the Computing Department. As a result of the changes, the Department is now responsible for delivering all aspects of mathematics, including GCSE and GCE (AS and A Level) mathematics and related qualifications, vocational mathematics, workplace mathematics, numeracy, Application of Number (AoN) and Adult Basic Skills Numeracy (ABSN). Before the current on-going changes (that were initiated as a result of the College's massive investment in buildings and equipment), $\mathrm{AoN}$ and $\mathrm{ABSN}$ were part of the School of Community Education and lecturers from the Depariment taught the two courses under an arrangement in which money was transferred from the School of Community Education Cost Centre to the School of Academic Studies Cost Centre, for the service provided by the mathematics lecturers. The changes meant that the mathematics offered in the Department underpinned both vocational and academic develop- ment, and all staff who taught mathematics and numeracy in the College reported to the Head of Mathematics Department (HMD).

The HMD was responsible for coordinating all mathematics activities across the College. He was also in charge of Continuing Professional Development (CPD) of all teachers of mathematics, and ensured the sharing of good practice, subject knowledge and pedagogical content knowledge. The Department made much effort to attract students to study mathematics and to ensure that students not only had a positive learning experience when studying mathematics, but that they developed positive attitudes to the subject and were well prepared for both higher education and employment. (Mathematics Self Assessment Report, 2008).

The college has a well-defined mathematics suite of rooms. These rooms are filled with interesting posters (on 2D and 3D shapes, formulae, application of mathematical concepts, etc) and models, and each room has at least ten computers. The use of ICT is much in evidence, both as a teaching tool and as a resource for students. Besides, the Department has mathematics intranet site (on Blackboard - the college intranet system) which is used by students to support independent learning. All common assignments and textbook worked solutions are available online, and staff have easy access to a database where they $\log$ and record all students' performance. This helps identify poor performance across the whole student base and enables effective strategies to deal with poor performance shared 
across the classes. Scores are recorded and 'graded' automatically, and students' details can be accessed easily by any lecturer.

The mathematics intranet site is maintained by all mathematics lecturers, and each has a responsibility for a mathematics module. The site uses many in-house resources and also uses the Mathematics in Education and Industry (MEI) distance learning site. It is indeed, not surprising that the Department was graded 'outstanding' by the Office for Standards in Education (Ofsted) inspectors in 2006.

\section{The Ofsted report read:}

Teaching and learning in mathematics are very good. Teachers use very effective strategies in mathematics lessons, exploiting well the DfES Standards Unit national pilot materials in activity-based learning. For example, in an advanced mathematics lesson, IT and Standards Unit materials and approaches were used very effectively to introduce the geometry of the circle. The active learning approach to teaching is transforming and revitalising learning. Lesson planning and schemes of work in mathematics are good, providing a sound basis for teaching and learning. In the best lessons, a wide range of learning activities challenges all students. Often, there is exceptional use of ICT in lessons. Students are well motivated and ask questions which display interest and understanding. Very good leadership in mathematics has successfully embedded the innovative activity-based approach in all programmes. (Ofsted, 2006, pp 7 8)
It is no exaggeration to posit that the Department (before the above changes) was a model department of the College and that all other departments had drawn inspiration from the successes of the mathematics department. It was against this background that the authors were commissioned to review the "new" Department ahead of the College's application for renewal of its Investor in People status. The renewal of the status involves an assessment by external assessors or by certified internal assessors supervised by an external assessor. The college opted for the latter and used the study as a "mock assessment".

\section{Purpose and background to the study}

The study of the Department took place in November, 2008. It was undertaken by the authors in order to find out the extent to which the Mathematics Department met the indicators of the new Standard in the face of the changes that were being implemented in the whole college. Since the Department was the most successful department in the College prior to the changes, it was hoped that it had taken the structural (and possibly cultural) changes in its stride and that any identified good practice (with regard to response to the changes) could be disseminated throughout the College. This was an important significance of the study.

The study was also indirectly investigating the impact of the changes on the College's Investors in People status, for if the Department did not meet any of the indicators (which it had met in the review before the structural changes), then this would help the 
College to identify which of the indicators was affected by the changes, considering that the new Standard was not significantly different from the earlier one (Investors in People, UK, 2005). This would mean finding ways of meeting the indicator(s) before the application for the renewal of the College's Investors in People status was made.

Put simply, the College had acknowledged that the changes could affect the views of staff generally and that it was important to take the ongoing changes into consideration in the IIP renewal venture. There is no gainsaying that improvements in business processes require change to an organisation's structure and culture. Yet, ariy significant change to the structure and culture is likely to be disruptive. Indeed, the various models which have been proposed which attempt to minimise the disruptive effects of organisational change while at the same time providing opportunities for improvements in the organization (e.g. Palmer, Dunford, \& Aikin, 2006) are based on the premise that improved processes ought to be successfully assimilated into the organisation's structure and culture. In other words, the models assume that organisational change involves both structural and cultura! change, and that there will always be resistance to change because of the "disruption" that is usually associated with the change.

As an important example of a change model (which informed our study), and without digressing from the main study, Kurt Lewin (Cited by Scott,
2007) described a model which he had developed earlier and which proposed a three-stage approach to change. The basic outline of the model is to first "unfreeze" the current situation so change can occur, then to make changes, and finally to "refreeze" the new situation in place. The first stage involves letting people appreciate the need for the change. It is important to point out that people often ask a number of questions the answers to which determine their ability to see the need for change. These questions include:

1. What sort of change is it?

2. How will the change affect me and my job?

3. How will I be evaluated?

4. How will this change be conducted?

5. What are the benefits?

6. What will the overall impact of the change be?

7. How can I help others with the change?

This series of questions is somewhat similar to Maslow's (1970) Needs Hierarchy. Maslow states that if a more basic level is not satisfied, a higher level will not be of importance to the organisational personnel. That is, if management cannot explain how the change will affect an employee (Question 2), then the employee will not help others change (Question 7). If employees are satisfied with the answers to basic questions as those stated above, then they are likely to see the need for the change in the first place. As (Cummings \& Worley, 2004) rightly point out, management programmes that ignore this theoretical framework can fail. 
The second stage of Lewin's model involves explaining what employees will be required to do under the new system. A powerful way to decrease resistance to change is to increase the participation of employees in making decisions about various aspects of the process. There are actually two reasons for employee participation. The more common reason is to increase employee commitment to the outcomes of the change, as they will have a sense of ownership in what is decided. A second reason is that employees have a great deal of knowledge and skill relevant to the issue at hand (e.g. increasing quality, identifying problems, and improving work processes), and their input should lead to higher quality decisions. The third and final stage of the model under discussion is taking measures to embed the change into people's thinking. Here the people involved in the change accept it and the change becomes incorporated into their understanding of the new system, which may later become part of their normal behaviour (Jones, 2008; Kotter, 1996).

It appears the most difficult stage of the model under discussion is the first one as employees may find it difficult to see the need for the change because they have not had the right answers to the questions posed above. The changes in the Department were ongoing and staff were far from certain about how to handle the first stage of Lewin's model. Therefore, as explained below, the questions that were used in the interviews reflected some of the ideas Lewin made about changes generally and the first stage of his model in particular.

\section{Methodology}

The IIP study was basically qualitative in nature. It was designed to collect views of people in the organisation about how best improvements could be planned, implemented and evaluated. In social science research parlance, our target population for the review consisted of all teaching and nonteaching staff in the Mathematics Department. The sampling frame for the review coincided with the target population since the staff in the Department were the units of analysis of the study. In an attempt to preserve the random principle on which statistical inferences depend, while at the same time allowing for a design that would ensure adequate representation of the staff in the Mathematics Department, the study used a stratified sampling method to select participants. Stratification was done by category of Staff. This design was preferred to simple random sampling of individual staff of the Department not only because it was to ensure that all categories of staff were adequately represented, but it also avoided the problem of the non-teaching staff seeing the whole exercise as something to do with teaching and learning only. As there were only two nonteaching staff among twenty-three staff the probability of choosing a member of the non-teaching staff using simple random sampling was significantly lower than that of choosing a member of the teaching staff by that method.

\section{Sample size}

Using the guidelines provided by Investors in People UK, regarding the selection of sample size, we selected 
14 participants which constituted the sample size of $61 \%$ of the populationalmost the same as the $60 \%$ recommended by Investors in people UK for the population size of $20-25$.
Table 1 shows the sampling frame and the number of staff selected from each category.

Table 1 Sampling Frame for the Study

\begin{tabular}{lllll}
\hline Category & Total & $\begin{array}{l}\text { Number } \\
\text { sampled }\end{array}$ & $\begin{array}{l}\text { Sample } \\
\text { proportion }\end{array}$ & $\begin{array}{l}\text { Comments } \\
\text { (scope of influence/ power) }\end{array}$ \\
Administrator & 2 & 1 & $50 \%$ & Lower in Scope \\
Lecturer (Part time) & 7 & 4 & $57 \%$ & Middle in scope \\
Lecturer (Full-time) & 12 & 7 & $58 \%$ & Middle in Scope \\
Head of Department & 1 & 1 & $100 \%$ & Higher in Scope \\
Senior Manager & 1 & 1 & $100 \%$ & Higher in scope \\
Total & $\mathbf{2 3}$ & $\mathbf{1 4}$ & $\mathbf{6 0 . 9 \%}$ & \\
\hline
\end{tabular}

\section{Instruments}

Preparations towards the development of the main instruments for the study involved a number of steps. Preparations began with the study of a number of IIP reviews and the materials used in them. This was followed by three meetings, which were attended by the author and the appointed external assessor in the previous whole college review, to discuss the construction of the interview schedule. The ideas we shared at these meetings helped us to select and modify the items with which we constructed individually and sent to the meetings. In the third and final meeting, we constructed three separate structured interview schedules for people (staff of lower and middle scope), the HMD and the senior manager in charge of the delivery of mathematics, respectively. We tested our instruments in a small pilot involving 4 senior members of the College and one administrator, who worked at a different site in a different department. The senior members were two lecturers, one Head of Department (a middle manager) and the Senior Manager (SM) in charge of teaching in the Science Department. Since these members of staff were also members of the School of Academic Studies, we thought their responses to the items would help us modify the latter for the main study. As a result of the pilot study, we amended a few of the interview items to meet the specific needs of the Mathematics Department. For example, items regarding whole school meetings were included to capture the line of communication within the Department as a whole. Also items regarding the use of the Department's budget for staff development were amended to take note of 
the specific needs on mathematics lecturers.

\section{Data collection}

The mechanics for collecting data for the study were straightforward. The researchers spent 17 days interviewing managers and other staff and looking at specific documents from the Department. The author also spent time with the HMD and the SM in charge of teaching and learning of mathematics in the College. They discussed the context of the Department, its aims and objectives, how it is managed and how its processes compare with the evidence requirements of the Standard. It must be pointed out that there is no obligation on any organization being assessed under IIP to present a single piece of paperwork to an external assessor or an internal review team. As Investors in People UK point out "Assessors are interested in the effect and impact of ... processes not the paperwork itself" (Investors in People UK, 2005, p.10).

However, because the Departments of the College tend to document systematically, there was no difficulty in the Department showing the researchers documents which were deemed helpful for the exercise. For example, the researchers looked at the 2008 Self Assessment Report for the Department as well as minutes of meetings detailing examples of internal communication, consultations, reviews and students' attainments. To supplement the managerial perspective, they also interviewed a sample of both part-time and full-time lecturers as well as one of the administrators in the Department to get their perceptions about the Department in particular and the College as a whole. The researchers kept assuring the participants during the interviews that the purpose of the interviews was not to 'catch people out' but simply to get a real insight into how the Department functions. They also assured participants of confiden-tiality and the fact that no part of the report would identify any individual who took part in the study.

Each interview took between thirty minutes and one hour in a designated room for the exercise. Apart from the author and the selected interviewees, no one was allowed into the interview room while an interview was in progress. During each of the interviews, we went through the interview schedule asking the relevant questions and capturing quotes. At the end of each interview, the author read the summary and the quotes to the interviewee who confirmed the accuracy of both the summary and the quotes. The author thanked the interviewee and reassured them of confidentiality. 
This procedure did not impose any significant limitation on the data, except that the reporting was done in such a way that no respondent was identified by those who had access to the report.

\section{The feedback}

At the end of the seventeenth day, the author met with management to give feedback on what had been found. As Investors in People UK observe, "this discussion is a key part of the assessment's value to the organisation by offering staff insights and suggestions about the organisation's operations which no other professional could provide" (Investors in People, 2005, p.11). As well as drawing on knowledge of practices in other organisations which the author was introduced to during their training as Internal Reviewers, they were also able to refer to good practice amongst staff in the Department in general. Furthermore, as the study was part of a process of continuous improvement, the author also identified areas he thought the Department had the opportunity to improve on. Indeed, "being an Investor in People means always being in a progressive and dynamic state" (Investors in People, 2005, p.12)

\section{Overall conclusion}

The overall conclusion of the researchers is that the "new" Mathematics Department of the College did not meet the Investors in People Standard as not all the indicators were met. As shown in Table 2, below, two out of the ten indicators were not met by the Department.

Table 2: Summary of Findings

\begin{tabular}{|c|c|c|c|c|c|c|c|c|}
\hline \multirow[t]{2}{*}{ Plan } & \multirow[b]{2}{*}{ Met } & \multirow[b]{2}{*}{ Not met } & \multicolumn{2}{|l|}{ Do } & & \multicolumn{2}{|l|}{ Evaluate } & \multirow[b]{2}{*}{ Not met } \\
\hline & & & & Met & Not met & & Met & \\
\hline Indicator & & $\mathrm{x}$ & Indicator & $\checkmark$ & & Indicator & $\checkmark$ & \\
\hline 1 & & & 5 & & & 9 & & \\
\hline Indicator & $\checkmark$ & & Indicator & $\checkmark$. & & Indicator & $\checkmark$ & \\
\hline 2 & & & 6 & & & 10 & & \\
\hline Indicator & $\checkmark$ & & Indicator & & $\mathrm{x}$ & & & \\
\hline 3 & & & 7 & & & & & \\
\hline Indicator & $\checkmark$ & & Indicator & $\checkmark$ & & & & \\
\hline 4 & & & 8 & & & & & \\
\hline
\end{tabular}




\section{Findings in detail}

Details of the findings of the study are outlined below:

Indicator 1. A strategy for improving the performance of the organisation is clearly defined and understood. (Not met)

Members of staff interviewed knew the mission of the College, recalled the main elements of the 2008 Strategic Plan and were also able to outline the main objectives of the Department with regard to performance improvement. However, the majority of the people sampled ( 9 out of 14 or $64 \%$ ) did not think they were consulted adequately on the development of the Strategic Plan and did not know how they were expected to achieve the College or the Department's objectives. One of the interviewees said: "The mission was developed by Policy Team and we were just told what it is.....that's no consultation, is it?"

Indicator 2. Learning and development is planned to achieve the organisation's objectives. (Met)

Staff obviously appreciated the availability of Learning and Development (L \& D) opportunities, saw them as a real advantage and commented on the range of activities. Specifically, staff were clear about the benefits of their $\mathrm{L} \& \mathrm{D}$ to themselves, their department and the College. Examples demonstrated an understanding of the costs and benefits of the development of people and their impact on performance. Managers also commented on the need to link $L$ $\&$ D opportunities to the Department's objectives and hence to be more 'directive' in approving staff requests.
This was seen as an important target for the following year's Staff Review process. A member of the junior staff remarked with enthusiasm: "I have the opportunity to go on courses to help me with my work"

Indicator 3. Strategies for managing people are designed to promote equality of opportunity in the development of the organisation's people (Met)

Both managers and other staff confirmed the existence of a system in place (e.g. annual reviews) to encourage managers and staff to take up relevant training and development opportunities, including secondments. Everyone interviewed felt that staff development opportunities were offered on an equal opportunities basis and that the College strategies for managing people were designed to promote equality of opportunity. One interviewee observed: "My manager is quite encouraging and gives all the staff equal chance of going onto a course". It was clear that people right across the Department were involved in working to achieve high levels of awareness and of practice in this regard. Thus the claim in the College's Strategic Plan (2008) that "all staff are considered to be equal and that the College seeks to support all of its employees through its management structures, training and development practices" (p.12) was confirmed by the staff who took part in the study. Furthermore, staff were engaged in a wide range of development activities designed to support individuals and teams in working to improve their current and future contribution within the Department's strategic priorities. 
Indicator 4. The capabilities managers need to lead, manage and develop people effectively are clearly defined and understood (Met)

Staff felt that managers were very organised, observant and efficient and that they managed very effectively staff performance and development. There seemed to be a ready understanding of the link between management capability and staff performance and quality. The staff interviewed made mention of the management charter and said they knew what was expected of their managers. The managers also seemed clear about their role and the skills needed to exercise it well. One of the managers pointed out that: "There are sufficient guidelines (for managers) and line managers are well supported." This view was shared by twelve out of the fourteen $(86 \%)$ managers and staff interviewed.

Indicator 5. Managers are effective in leading, managing and developing people. (Met)

Managers gave regular, timely and specific feedback to staff about their work performance - delivered at a time when the staff could do something about it, and not saved up for a future review! One respondent said: "I like it when I get feedback about my work at the time when I can do something to change my way of working."

Indicator 6. People's contribution to the organisation is recognised and valued (Met)

Staff commented that their managers (i.e. both the HMD and the SM) went out of their way to recognise and value them. There were examples of staff receiving e-mails to congratulate them on significant successes and also timely words of appreciation. Managers also recognised the power of positive words of encouragement. Furthermore, the Merton College newsletter, Snippets, was seen by the majority of staff as an effective vehicle for the exchange of internal news and helped to celebrate achievements. Staff in the Department shared news of progress and reported that their efforts were appreciated by managers. One member of staff said: "Words of encouragement and thanks from the head make me feel valued".

\section{Indicator 7. People are encouraged} to take ownership and responsibility by being involved in decisionmaking. (Not met)

The vast majority (10 out of 12 or $83 \%$ ) of the lecturers and administrator (excluding the HMD and the SM) interviewed did not think they were encouraged to take ownership and responsibility for decisions that affected their performance and the performance of the Department. Eight respondents thought the HMD encouraged too much consultation and this made them feel the Department could not achieve anything without consulting the leadership of the College. The majority of the staff interviewed thought decisions were taken by senior managers and they were simply "cajoled" to go along with the decisions. One member of staff who was very critical of management throughout the interview remarked: "I totally feel disempowered...(I am) given no free reign to implement any decisions at tutorials" 
Indicator 8. People learn and develop effectively. (Met)

Staff and managers commented on the broad range of effective staff development opportunities and felt they were developing in a continuous way through staff reviews. The majority of the staff confirmed that line managers were effective in supporting them meet their development needs and understood how they had applied their learning in their roles. Staff were given the opportunity to engage in a rich range of targeted development activities which help them to tackle challenging aspects of their job with new confidence, skills and insights. Staff induction was given careful attention and the majority of the staff were impressed by its thoughtfulness. One new member of staff remarked: "Induction is taken seriously - all team leaders are involved in this". A couple of staff however felt that although the Staff Induction programme had changed recently for the better, they still felt there was a need for further development - or at least fine tuning. On the whole, both staff and management were happy about the development opportunities that were available to them in the College.

\section{Indicator 9. Investment in people improves the performance of the organisation. (Met)}

Staff commented with warm approval about the various development opportunities available to them. Often mentioned was "Learning to Lead" a management development programme for aspiring managers which seemed to have been enthusiastically received by all the staff who participated. Managers described how the impact of investment in learning and development was measured. Indicators mentioned include low staff absence levels; more staff with IT skills; only I "untrained" lecturer was left to be teacher-trained in the part-time category. Managers also provided examples of how learning and development had improved communication and collaboration. One of the managers said: "The numeracy and the (pure) mathematics teams have come together and this had produced significant synergy and improved the department's performance". This was confirmed by staff who thought that the learning and development they had received improved their own performance, that of the Department and that of the College as a whole.

\section{Indicator 10. Investment in people improves the performance of the organisation. (Met)}

Both staff and managers commented favourably on the College's ability to manage, develop and get the most out of people. Managers provided examples of how the college was committed to continuous improvements in the development of staff and how their cost-benefit analysis of learning and development had helped them to better manage and develop people. Examples included the funding of "new teachers' forum" and "aspiring managers" programmes. The majority of the people interviewed (11 out of 14 or $79 \%$ ) were able to give specific examples of improvements that had been made to the way they were managed and developed. One of the staff said: "The HMD is open to suggestions and this has made him more approachable now than before". 


\section{Discussion}

Generally, managers were able to demonstrate an understanding of how to count the costs and benefits of learning and development and the latter's impact on the performance of individuals, the Department and the College as a whole. Management of the Department were clear about strategies focused on developing people to improve performance and had taken steps to ensure that all staff had equality of access to learning and development opportunities. This was acknowledged by nearly all the people sampled. Managers and people celebrated continuous improvements in the way people were managed and developed to improve performance. The staff's contributions were recognised and valued and this encouraged their involvement in team planning and sharing of ideas and best practice. The staff were very praiseworthy of their line manager who ran an 'open door' type of policy where the staff felt they could be listened to at any time about work or personal matters.

While there was some verbal evidence to confirm that the senior manager and the HMD knew and understood the strategic aims and objectives of the College, the majority of the people interviewed (about 64\%) had limited knowledge of these aims and objectives. People's limited understanding of the strategic aims and objectives of the College were put down to lack of consultation by senior management in the development of such aims and objectives. Staff felt they were not always involved in decision making in the Department and that they were not encouraged to put forward ideas. In several areas they were not encouraged to try things out and to learn from their mistakes.

Campbell and Alexander (1997) have observed that directionless strategies result when strategists fail to distinguish between purpose (what an organization exists to do) and constraints (what an organization must do in order to survive). According to the majority of the non-senior respondents (about $83 \%$ ), there was a lack of clear distinction between the purpose and constraints in the College's strategic plan and this made it difficult for them to identify the value they were adding or could add to the work of the College. Yet, the basic ingredient of a good strategy is insight into how people can create value to the organization (Campbell and Alexander). The answer to developing a good strategy (as far as our study is concerned) is to understand both the benefit of having a well-articulated, stable purpose and the importance of discovering and exploiting insights about how to create more value as an organization. As Burnes (2004) rightly observes, in order to be successful, organizations must establish a flexible but clear strategic direction with a team-based organiza-tional concept and supporting systems in place.

With regard to people in an organization being encouraged to take ownership and responsibility by being involved in decision-making, Black and Hall (2002) have pointed out that change is effected successfully by democratic leaders and transformational leaders who encourage participation of members in the 
process. Indeed, there is the need to get staff involved fully in the identification of what needs to be changed, the development of a plan, the implementation and evaluation of the change after the change has been effected. In other words, all the people involved in the change should feel part of the change process. There is no gainsaying that management and employees tend to see change differently. To the manager, change means opportunity but to the employee, it may seem disruptive, imposed, and intrusive. An important way of overcoming employees' resistance to change is therefore by redefining their roles from mere implementers of change to both authors and implementers of change.

\section{Conclusion and recommendation}

Having carried out the study rigorously and in accordance with the guidelines provided for Assessors by Investors in People UK, the author is confident about the validity of the overail conclusion that the Mathematics Department of Merton College does not meet the requirements of the Investors in People Standard. If the findings of the study under discussion are anything to go by, then if College were to be reassessed by an External Assessor it would not meet the requirements necessary to achieve accreditation against the revised Investors in People Standard.

This is because to achieve accreditation, all aspects of every indicator must be judged to be met.

It is therefore recommended that Policy Team should develop an Action
Plan to address some of the key issues identified. Since the Mathematics Department met all the indicators when the College was last assessed, it would appear that the current changes have not been "accepted" by all staff of the Department. For example, staff who joined the Department as a result of the current changes were generally negative in their responses to the items about the level of support they get from the Department. It is therefore important to target this category of staff for sensitization of the changes in the Department.

Finally, by way of recommendation, it may be helpful to conduct such studies on a regular basis to find out when the changes that the College has implemented will be "fully" accepted by members of staff in the Mathematics Department as well as other schools and departments of the College.

\section{References}

Black, J. S., \& Hall, B. G. (2002). Leading strategic change. New Jersey: Financial Times Prentice Hall.

Burnes, B. (2004). Managing change: A strategic approach to organisational dynamics $\left(3^{n}\right.$ ed). London: Pearson

Cameron, E., \& Green, M. (2004). Making sense of change management: A complete guide to the models, tools and techniques of organizational change. London: Kogan Page 
Cummins, T., \& Worley, C. (2004). Organization development and change ( $8^{\text {th }}$ e d ). South Western Publishing Investors in People, UK (2005). The new investors in people standard. London: Investors in People, UK

Jones, I. (2008). The human factor: Inside the CIA's dysfunctional intelligence culture. New York: Encounter Books.

Kotter, J. (1996) Leading change. Boston, Massachusetts: Harvard Business School Press

Kotter, J. P. \& Cohen, D. S. (2002). The heart of change. Boston, Massachusetts: Harvard Business School Press.

Lawler E., \& Worley, C (2006). Built to change: How to achieve sustained organisa tional effectiveness . London: John Wiley \& Sons

Mathematics Assessment Report (2008). Departmental Reportfor 2008. London: Merton College
Maslow, A.H. (1970). Motivation and personality (2nd Ed.). New York: Harper and Row.

McGregor, D.M. (1960). The human side of enterprise. New York: McGraw-Hill

Merton College Strategic Plan (2008). Strategic Plan for 2008. London: Merton College. UK

Palmer, I., Dunford, R., $m$ \& Akin,G.(2006). Managing Organisational Change: A multiple perspectives approach. New York: McGraw Hill Irwin.

Ofsted (2006). Inspection Report on Merton College. London: Office for Standards in Education

Scott, W. R. (2007). Organizations and organizing: Rational, natural, and open systems perspectives.

London: Pearson Prentice Hali

Senior, B. \& Fleming, J. (2005). Organisational change $\left(2^{\text {nd }}\right.$ ed). London: Prentice Hall

\section{Appendix A}

Investors in People Evidence Criteria 


\begin{tabular}{|c|c|}
\hline $\begin{array}{l}\text { Evidence } \\
\text { Criteria }\end{array}$ & \\
\hline 1.1 & $\begin{array}{l}\text { Top managers make sure the organisation has a clear purpose and vision } \\
\text { supported by a strategy for improving its performance. }\end{array}$ \\
\hline 1.2 & $\begin{array}{l}\text { Top managers make sure the organisation has a business plan with measurable } \\
\text { perforninance objectives }\end{array}$ \\
\hline 1.3 & $\begin{array}{l}\text { Top managers make sure there are constructive relationships with representative } \\
\text { groups (where they exist) and the groups are consulted when developing the } \\
\text { organisation's business plan. }\end{array}$ \\
\hline 1.4 & $\begin{array}{l}\text { Managers can describe how they involve people when developing the } \\
\text { organisation's business plan and when agreeing team and individual objectives. }\end{array}$ \\
\hline 1.5 & $\begin{array}{l}\text { People who are members of representative groups can confirm that top managers } \\
\text { make sure there are constru ctive relationships with the groups and they are } \\
\text { consulted when developing the organisation's business plan. }\end{array}$ \\
\hline 1.6 & $\begin{array}{l}\text { People can explain the objectives of their team and the organisation at a level that } \\
\text { is appropriate to their role, and can describe how they a re expected to contribute } \\
\text { to developing and achieving them. }\end{array}$ \\
\hline 2.1 & $\begin{array}{l}\text { Top managers can explain the organisation's learning and development } \\
\text { needs, the plans and resources in place to meet them, how these link to } \\
\text { achieving specific objectives and how the impact will be evaluated. }\end{array}$ \\
\hline 2.2 & $\begin{array}{l}\text { Managers can explain tean learning and development needs, the activities } \\
\text { planned ro meet them, how these link to achieving specific team objectives and } \\
\text { how the impact will be evaluated. }\end{array}$ \\
\hline 2.3 & $\begin{array}{l}\text { People can describe how they are involved in identifying their learning and } \\
\text { development needs and the activities planned to meet them }\end{array}$ \\
\hline 2.4 & $\begin{array}{l}\text { People can explain what their learning and development activities should achieve } \\
\text { for them, their team and the organisation. }\end{array}$ \\
\hline 3.1 & $\begin{array}{l}\text { Top managers can describe stra tegies they have in place to create an environment } \\
\text { where everyone is encouraged to contribute ideas to improve their own and other } \\
\text { people s performance }\end{array}$ \\
\hline 3.2 & $\begin{array}{l}\text { Top managers recognise the different needs of people and can describe strategies } \\
\text { they have in place to make sure everyone has appropriate and fair access to the } \\
\text { support they need and there is equality of opportunity for people to learn and } \\
\text { develop which will improve their performance }\end{array}$ \\
\hline 3.3 & $\begin{array}{l}\text { Managers recognise the different needs of people and can describe how they make } \\
\text { sure everyone has appropriate and fair access to the support they need and there } \\
\text { is equality of opportunity for people to learn and develop which will improve their } \\
\text { performance }\end{array}$ \\
\hline 3.4 & $\begin{array}{l}\text { People believe managers are genuinely committed to making s ure everyone } \\
\text { has appropriate and fair access to the support they need and there is } \\
\text { equality of opportumity for them to learn and develop which will improve } \\
\text { their performance. }\end{array}$ \\
\hline 3.5 & $\begin{array}{l}\text { People can give examples of how they have been encouraged to contribute idea } s \\
\text { to improve their own and other people's performance }\end{array}$ \\
\hline 4.1 & $\begin{array}{l}\text { Top managers can describe the knowledge. skills and behaviours managers } \\
\text { need to lead, manage and develop people effectively, and the plans they } \\
\text { have in place to make sure managers have these capabilities. }\end{array}$ \\
\hline 4.2 & $\begin{array}{l}\text { Managers can describe the knowledge, skills and behaviour's they need to lead. } \\
\text { manage and develop people effectively }\end{array}$ \\
\hline
\end{tabular}




\begin{tabular}{|c|c|}
\hline 4.3 & $\begin{array}{l}\text { People can describe what their manager should be doing to lead. manage and } \\
\text { develop them effectively. }\end{array}$ \\
\hline 5.1 & $\begin{array}{l}\text { Managers can explain how they are effective in leading, managing and developing } \\
\text { people. }\end{array}$ \\
\hline 5.2 & $\begin{array}{l}\text { Managers can give examples of how they giv e people constructive feedback on } \\
\text { their performance regularly and when appropriate }\end{array}$ \\
\hline 5.3 & $\begin{array}{l}\text { People can explain how their managers are effective in leading, managing and } \\
\text { developing them. }\end{array}$ \\
\hline 5.4 & $\begin{array}{l}\text { People can give examples of how they receive constructive feedback on their } \\
\text { performance regularly and when appropriate }\end{array}$ \\
\hline 6.1 & $\begin{array}{l}\text { Managers can give examples of how they recognise and value people s individual } \\
\text { contribution to the organisation }\end{array}$ \\
\hline 6.2 & $\begin{array}{l}\text { People can describe how they contribute to the organisation and betieve they } \\
\text { make a positive difference to its performance. }\end{array}$ \\
\hline 6.3 & $\begin{array}{l}\text { People can describe how their contribution to the organisation is recognised and } \\
\text { valued. }\end{array}$ \\
\hline 7.1 & $\begin{array}{l}\text { Managers can describe how they promote a sense of ownership and responsibility } \\
\text { by encouraging people to be involved } i \text { decision-making, both individually and } \\
\text { through representative groups. where they exist. }\end{array}$ \\
\hline 7.2 & $\begin{array}{l}\text { People can describe how they are encouraged to be involved in decision -making } \\
\text { that affects the performance of individuals, teams and the organisation. at a level } \\
\text { that is appropriate to their role. }\end{array}$ \\
\hline 7.3 & $\begin{array}{l}\text { People can describe how they are encouraged to take ownership and } \\
\text { responsibility for decisions that affect the performance of individuals, teams and } \\
\text { the organisation. at a level that is appropriate to their role. }\end{array}$ \\
\hline 8.1 & $\begin{array}{l}\text { Managers can describe how they make sure people's learning and development } \\
\text { needs are met. }\end{array}$ \\
\hline 8.2 & $\begin{array}{l}\text { People can describe how their learning and development needs have been met. } \\
\text { what they have learnt and how they have applied this in their role. }\end{array}$ \\
\hline 8.3 & $\begin{array}{l}\text { People who are new to the organisation, and those new to a role. can describe } \\
\text { how their induction has helped them to perform effectively }\end{array}$ \\
\hline 9.1 & $\begin{array}{l}\text { Top managers can describe the organisation's overall investment of time. money } \\
\text { and resoutces in learning and development. }\end{array}$ \\
\hline 9.2 & $\begin{array}{l}\text { Top managers can explain, and quantify where appropriate, how learning and } \\
\text { development has improved the performance of the rganisation. }\end{array}$ \\
\hline 9.3 & $\begin{array}{l}\text { Top managers can describe how the evaluation of their investment in people is } \\
\text { used to develop their strategy for improving the performance of the organisation. }\end{array}$ \\
\hline 9.4 & $\begin{array}{l}\text { Managers can give examples of how learning and development has } \\
\text { improved the performance of their team and the organisation. }\end{array}$ \\
\hline 9.5 & $\begin{array}{l}\text { People can give examples of how learning and development has improved th eir } \\
\text { performance, the performance of their team and that of the organisation }\end{array}$ \\
\hline 10.1 & $\begin{array}{l}\text { Top managers can give examples of how the evaluation of their investment in } \\
\text { people has resulted in improvements in the organisation's strategy for managing } \\
\text { and developing people. }\end{array}$ \\
\hline 10.2 & $\begin{array}{l}\text { Managers can give examples of improvements they have made to the way they } \\
\text { manage and develop people. }\end{array}$ \\
\hline 10.3 & $\begin{array}{l}\text { People can give examples of improvements that have been made to the way the } \\
\text { organisation manages and develops its people }\end{array}$ \\
\hline
\end{tabular}

